Avaliable online at http://e-journal.unipma.ac.id/index.php/gulawentah

\title{
TRADISI MENGIBUNG (STUDI KASUS SINGKRETISME AGAMA DI KAMPUNG ISLAM KEPAON BALI)
}

\author{
Riza Wulandari \\ STMIK STIKOM BALI \\ Email: rizawulandari@stikom-bali.ac.id
}

\begin{abstract}
Abstrak
Pembauran tradisi, budaya, dan agama yang memiliki jiwa toleransi akan menciptakan persatuan. Dewasa ini,Indonesia berada dalam krisis intoleran umat beragama yang semakin membuat keresahan. Sinkritisme merupakan konsep pembauran agama yang menciptakan keharmonisan. Di Bali, ada tradisi yang dijalankan oleh dua agama Hindu dan Islam yaitu Tradisi Megibung. Penelitian ini bertujuan untuk menggambarkan sinrketisme yang terjadi di salah satu kampung kota yakni Kampung Islam Kepaon. Penelitian kualitatif dengan metode studi kasus digunakan untuk menggali informasi secara mendalam menggunakan wawancara,observasi dan dokumentasi. Hasil penelitian ini adalah sinkretisme Kampung Islam Kepaon diwujudkan dengan menjalankan tradisi Megibung.Tindakan tradisional tradisi megibung berawal dari Karangasem Bali kemudian menyebar ke Kampung Islam Kepaon.Tujuan dari aktualisasi tradisi megibung di Kampung Islam Kepaon adalah untuk mempertahakan kearifan lokal masyarakat Bali dan menciptakan pluralism.Tradisi tersebut dijalankan dengan penuh toleransi namun masih berpegang teguh pada norma agama. Proses megibung dilaksanakan pada bulan Ramadhan, prosesidi kampung islam kepaon sama dengan megibung di Karangasem. Hal yang membedakan hanya menu makanan yang disajikan.Kesamaan pemaknaan tradisi megibung antar Hindu dan Islam adalah kebersamaan.
\end{abstract}

Kata kunci: sinkretisme, tradisi megibung, Kampung Islam Kepaon

\section{Megibung Tradition (A Case Study on Religion Syncretism in Kepaon Islamic Village, Bali)}

\begin{abstract}
The intermingling of tradition, culture, and religion of the soul of tolerance will create unity. Today, Indonesia is in a crisis of religious intolerant that increasingly make the disquiet. Syncretism is the concept of intermingling of religion that creates harmony. In Bali, there is a tradition that is run by two Hindu and Islamic Traditions, namely Megibung. This study aims to describe the Syncretism that occurred in one of the cities village is Kepaon Islamic Village. Qualitative research in methods of case studies were used to dig up information in depth using interviews, observation and documentation. The results of this research is the Hometown of Islam syncretism Kepaon embodied by running the Megibung tradition. Megibung tradition traditional action based in the Karangasem Bali then spread to Islam Kepaon. The purpose of actualizing the tradition megibung in Kampung Kepaon Islam is to maintain the local Balinese people and wisdom create pluralism. The tradition of tolerance run with yet still cling to a religious norm. Process megibung carried out in the month of Ramadan, Islamic processions in kampung kepaon equals megibung in Karangasem. The thing that distinguishes the only meal served. Definition of the megibung tradition in common between Hinduism and Islam is togetherness
\end{abstract}

Keyword: Syncretism, Megibung Tradition, Kepaon Islamic Village 


\section{Pendahuluan}

Bangsa Indonesia memiliki keberagaman identitas nasional yang harus dilestarikan oleh penerus bangsa. Suku, ras, budaya dan tradisi merupakan indikator dari Identitas Nasional bangsa Indonesia. Seperti yang terjadi di Bali, keberagaman ras, suku, tradisi dan budaya dari berbagai daerah di Indonesia bahkan dari Mancanegara ikut membaur menjadi satu. Namun hal tersebut masih tetap didominasi oleh masyarakat Bali Age dan umat hindu. Pada dasarnya manusia, tradisi dan kebudayaan tidak bisa dipisahkan, hal itu diaktualisasikan dengan masih adanya penanaman nilainilai luhur dari tradisi yang masih dijalankan oleh masyarakat Bali. Koentjaraningrat mengungkapkan kebudayaan dimaknai sebagai keseluruhan sistem gagasan, tindakan, dan hasil karya manusia dalam kehidupan masyarakat yabg dijadikan milik diri manusia dengan cara belajar. (Koentjaraningrat, $1980: 193$ ).

Tradisi adalah segala tindakan yang ajeg dilakukan di suatu daerah secara turun temurun. Tradisi merupakan kesamaan benda material dan gagasan yang berasal dari masa lalu namun masih ada sampai saat ini. Tradisi dapat didefinisikan sebagai warisan yang benar atau warisan masa lalu.(P.Stompka, 2010 : 69). Pengertian tersebut berarti apapun yang dilakukan oleh manusia secara turun-temurun dari setiap aspek kehidupannya yang merupakan upaya untuk meringankan hidup manusia dan dapat dikatakan sebagai tradisi. Tradisi merupakan bagian dari kebudayaan yang diwariskan dan diteruskan oleh para generasi dengan memegang teguh pada norma-norma, adat istiadat, kaidah-kaidah, harta-harta. Tradisi dapat luntur seketika dengan adanya aneka ragam perbuatan manusia. Lunturnya tradisi terkadang disebabkan oleh penolakan dari manusia itu sendiri yang enggan untuk mempertahankan dan menggantikan dengan budaya baru. (Van Peursen, 1988).

Beberapa ahli mengemukakan bahwa tradisi muncul dari perombakan masa lalu yang diaktualisasikan di masa kini. Secara terminologi tradisi mengandung pengertian tersembunyi tentang adanya kaitan masa lalu dan masa kini,hal itu ditunjukkan kepada sesuatu yang diwariskan oleh masa lalu namun masih berwujud dan berfungsi pada masa dewasa ini. Tradisi mempertontonkan aktivitas masyarakat dalam bertingkah laku baik dalam kehidupan yang bersifat duniawi maupun rohani atau keagamaan. Pola perilaku dalam tradisi diatur melalui pola hubungan manusia satu dengan manusia lain atau kelompok lain, bagaimana hal itu bertindak terhadap lingkungannya dan berperilaku terhadap alam lain. Perilaku tersebut berkembang menjadi suatu sistem yang memiliki pola dan norma yang mengatur penggunaan hukuman dan ancaman terhadap penyimpangan sosial atau pelanggaran dari tradisi tersebut.Sinkretismehadir sebagai pencampuran antara dua tradisi atau lebih dan terjadi lantaran masyarakat mengadopsi suatu kepercayaan dan berusaha untuk tidak terjadi benturan dengan gagasan dan praktek budaya lama.(Mulder, Niels. 1992 :285) 
Simuh mengemukakan bahwa sinkretis merupakan suatu sikap atau pandangan yang tidak mempersoalkan benar salahnya suatu agama.Sikap dalam hal ini tidak mempersoalkan murni atau tidak murninya suatu agama.Pemahaman terhadap sinkretis dimana semua agama dipandang baik dan benar.Penganut paham sinkritisme suka memadukan unsur-unsur dari berbagai agama, yang pada dasarnya berbeda. Sinkretisme juga didefinisikan sebagai mencampurkan idea dan praktek agama,hal ini maksudnya adalah salah satu mengambil sedikit atau banyak prinsip atau keduanya bersatu (amalgamasi) secara cosmopolitan dan sedikit bentuk politeistik.

Kampung Islam Kepaon adalah sebuah potret kampung berbasis islam yang menanamkan nila-nilai luhur dan tradisi keislaman. Kehidupan sosiokultural di kampung tersebut sangat kuat dengan identitas agama islam. Hal tersebut terlihat dari simbol, tanda dan identitas diri yang melekat pada masyarakat kampung islam kepaon diantaranya seperti adanya masjid yakni Masjid Yayasan Al Muhajirin,adanya simbol-simbol di setiap rumah masyarakat kampung islam Kepaon, adanya aktivitas keislaman,adanya simbol wanita umat islam dengan menggunakan hijab atau kerudung. Berada ditengah kompleksitas umat hindu, masyarakat kampung islam mencoba untuk mengaktualisasikan keberadaan mereka agar tetap bertahan salah satunya dengan pencampuran dua tradisi yang disebut sebagai sinkretisme. Bukan menjadi hal yang langka jika berbicara tentang tradisi di Bali.
Berbagai macam tradisi dijalankan oleh masyarakat Bali khususnya umat hindu, salah satunya tradisi Megibung. Menariknya tradisi Megibung juga dijalankan oleh umat Islam yang tinggal di Kampung Islam Kepaon Denpasar dan dilestarikan sampai saat ini. Penelitian ini bertujuan untuk mengetahui bagaimana sinkritisme tradisi megibung yang dilakukan di kampung islam kepaon dimana kampung tersebut didominasi oleh umat Islam.

\section{Metode Penelitian}

Penelitian jenis kualitatif merupakan jenis penelitian yang mendeskripsikan sebuah permasalahan secara jelas dalam sebuah penelitian. Menurut Bodgan dan Taylor (1975) bahwa penelitian kualitatif merupakan prosedur penelitian yang menghasilkan data deskriptif berupa kata-kata tertulis atau lisan dari orang-orang dan perilaku yang dapat diamati (Basrowi dan Suwandi, 2008 : 21). Laporannya berisi pengamatan dari berbagai kejadian dan kondisi di tempat penelitian. Tujuan akhir dari penelitian kualitatif adalah untuk memahami apa yang dipelajari dari perspektif itu sendiri dari sudut pandang kejadiannya itu sendiri. Jadi dalam hal ini, penelitian kualitatif merupakan pilihan yang tepat untuk menjelaskan segala sesuatu secara mendalam dan menyeluruh.

Dalam melakukan penelitian jenis kualitatif ini akan digunakan metode studi kasus. Menurut Robert K.Yin studi kasus adalah satu impuiri , empiris, yang menyelidiki fenomena dalam konteks kehidupan nyata, bila mana batas-batas antara fenomena dan konteks tak tampak 
dengan tegas, dan di mana multisumber bukti dimanfaatkan. Studi kasus lebih banyak berkutat dan atau berupaya menjawab pertanyaan-pertanyaan “ How", (bagaimana) dan "Why" (mengapa), serta pada tingkatan tertentu juga menjawab pertanyaan "What"(apa/apakah), dalam kegiatan penelitian (Bungin, 2005).

Studi kasus adalah salah satu metode penelitian dalam ilmu sosial. Penelitian yang menggunakan metode ini dilakukan pemeriksaan longitudinal yang mendalam terhadap suatu keadaan atau kejadian yang disebut sebagai kasus dengan menggunakan cara-cara yang sistematis dalam melakukan pengamatan, pengumpulan, analisis informasi dan pelaporan hasil yang telah dicapai. Sebagai hasil yang telah diperoleh, terdapat sebuah pemahaman yang mendalam tentang mengapa sesuatu terjadi dan dapat menjadi dasar bagi penelitian selanjutnya. Studi kasus dapat digunakan untuk menghasilkan dan menguji. Studi kasus juga disebut sebagai strategi penelitian, penelakan empiris yang menyelidiki suatu gejala dalam latar kehidupan nyata. Dalam studi kasus dapat menggunakan bukti yang bersifat kuantitatif maupun kualitatif (Yin, 2014). Pada dasarnya, penelitian studi kasus jamak adalah penelitian yang menggunakan lebih dari satu kasus. Penggunaan jumlah kasus lebih dari satu pada penelitian studi kasus pada umumnya dilakukan untuk mendapatkan data yang lebih detail, sehingga deskripsi hasil penelitian menjadi semakin jelas dan terperinci. Hal ini juga didorong oleh keinginan untuk menggeneralisasi konsep atau teori yang dihasilkan. Dengan kata lain, penggunaan jumlah kasus yang banyak dimaksudkan untuk menutupi kelemahan yang terdapat pada penggunaan kasus tunggal, yang dianggap tidak dapat digeneralisasikan.

Proses analisis pada penelitian studi kasus ganda berbeda dengan penelitian kuantitatif yang menggunakan jumlah responden yang banyak. Pada penelitian kuantitatif, data dari responden dapat diolah secara terintegrasi dengan formula tertentu, sehingga menghasilkan satu kesatuan konsep dalam bentuk model hubungan antar data. Di dalam penelitian studi kasus ganda,menyarankan menggunakan logika replikasi sebagai pendekatan di dalam proses analisisnya. Pada proses ini, setiap kasus harus mengalami prosedur penelitian yang sama, hingga menghasilkan hasil penelitiannya masing-masing. Selanjutnya, hasil dari masing-masing penelitian di perbandingkan, untuk menentukan kesamaan dan perbedaannya. Hasilnya dipergunakan untuk menjelaskan pertanyaan penelitian pada umumnya dan khususnya pencapaian atas maksud dan tujuan penelitian. Dalam strategi pendekatan studi kasus ini peneliti ingin menemukan serta menjawab.

Dalam penelitian sosial data merupakan hal yang krusial yang harus dimiliki oleh seorang peneliti. Dalam pengumpulan data beberapa hal yang harus diperhatikan adalah mengumpulkan data penelitian yang akan dilakukan dengan beberapa teknik. Melalui observasi, wawancara secara mendalam (deep interview), 
Avaliable online at http://e-journal.unipma.ac.id/index.php/gulawentah

dokumentasi atau foto merupakan cara yang dipilih oleh peneliti untuk memecahkan permasalahan yang ada.

Dalam penelitian yang akan dilakukan menggunakan dua sumber data yaitu Data Primer dan Data Sekunder. Data Primer adalah data yang berkaitan dengan inti permasalahan dalam penelitian yang diperoleh dari sumbernya melalui penelitian di lapangan,observasi dan wawancara. Sedangkan data sekunder adalah data yang bersumber dari buku, artikel, Koran, serta bacaan-bacaan lain yang berkaitan dengan tema penelitian. Dalam data primer merupakan data yang didapat dari sumber pertama, baik dari individu atau perseorangan seperti wawancara atau hasil pengisian kuesioner yang biasa dilakukan oleh peneliti. Dalam penelitian kualitatif data primer didapatkan melalui kegiatan wawancara langsung terhadap informan, observasi terhadap suatu kasus tertentu. Sedangkan dalam penelitian ini sendiri data primer didapat dari wawancara terhadap informan yang dianggap mengetahui informasi dan masalah yang diteliti secara mendalam dan dapat dipercaya untuk menjadi sumber data yang valid. Selain itu, data primer dalam penelitian ini juga digali melalui observasi atau pengamatan langsung terhadap peristiwa dan objek yang terkait dengan tujuan penelitian. Sedangkan pada data sekunder adalah data yang diperoleh secara tidak langsung dan sering disebut metode penggunaan dokumen, karena dalam hal ini peneliti tidak secara langsung mendapatkan data dari informan atau individu tetapi memanfaatkan data yang telah dihasilkan atau diolah oleh pihak lain. Data sekunder ini dapat diperoleh melalui buku-buku, kepustakaan, dokumentasi dan keterangan lain yang berhubungan dengan masalah yang akan diteliti dan kemudian digunakan sebagai pendukung dan pelengkap data primer. Dalam penelitian ini, data sekunder diperoleh melalui buku-buku, kepustakaan, majalah/jurnal, dokumen, arsip serta sumber-sumber dari internet yang menyediakan banyak data sekunder.

Teknik analisis data adalah yang digunakan untuk menganalisa dengan model interaktif (Interactive Mode of Analysis). Menurut, tahap-tahap dalam analisis data yakni Reduksi Data, Penyajian Data dan Penarikan kesimpulan. Setelah data terkumpul dilakukan analisa melalui tiga komponen yaitu reduksi data, penyajian data, dan penarikan kesimpulan dengan verifikasinya. Ketiga komponen ini saling berinteraksi dan berkaitan satu sama lain sehingga tidak dapat dipisahkan dari kegiatan pengumpulan data, oleh karenanya analisis data dapat dilakukan sebelum, selama dan setelah proses pengumpulan data di lapangan. Dengan adanya alur tersebut, peneliti mula-mula akan membaca catatan lapangan, mendengarkan rekaman wawancara, membaca transkip wawancara untuk mendapatkan pemahaman tetang perihal yang dikaji. Pada tahap ini peneliti dapat menambahkan beberapa yang mungkin diperlukan. Catatan tersebut bisa berupa kesimpulan sementara atau wawasan yang muncul begitu saja. Pada tahap selanjutnya , peneliti dapat 
Avaliable online at http://e-journal.unipma.ac.id/index.php/gulawentah

menggunakan sisi.Penelitian ini dilakukan di salah satu daerah yang ada di pusat wilayah Kota Denpasar tepatnya Denpasar Selatan. Kepaon adalah salah satu daerah yang ada di Denpasar
Selatan tepatnya Desa Pemogan. Peta Kampung Islam Kepaon dapat dilihat pada Gambar 1. Peta Kampung Islam Kepaon

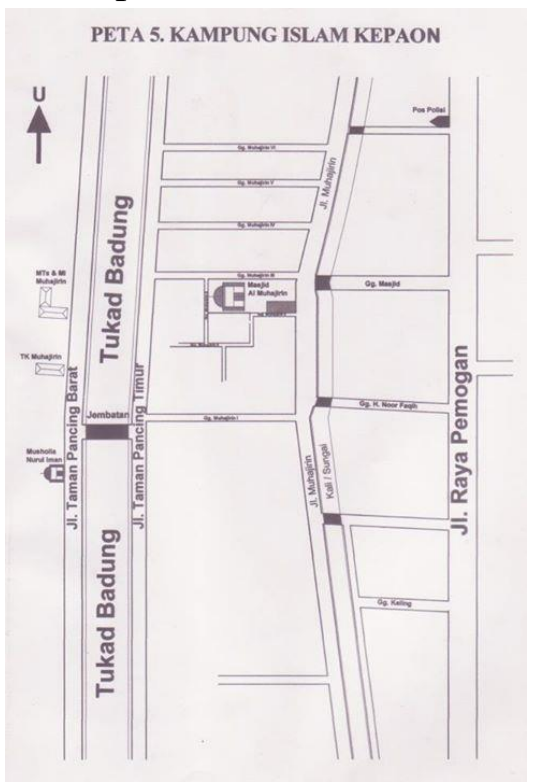

\section{Gambar 1. Peta Kampung Islam Kepaon}

\section{Hasil dan Pembahasan}

Tradisi Megibung : Wujud Sinkretisme Hindu dan Islam

Desa Pemogan terletak di Kecamatan Denpasar selatan dengan batas-batas wilayah yakni sebelah utara Desa Pakraman Pedungan, sebelah timur Desa Pakraman Pedungan, di selatan Desa Pakraman Kepaon dan sebelah barat Subak Abian Base Pemecutan Kelod dan Dauh Puri Kauh. Desa Pemogan memiliki kunci kehidupan yakni kebenaran adalah dasar untuk mencapai kesucian tertinggi. Pada Desa Pamogan Kepaon memiliki desa adat berjumah tiga diantaranya adalah Adat Pemogan dan Desa adat Kepaon serta Desa Adat Islam Kepaon. Proses penyebutan nama Desa Adat Islam Kepaon akhirnya menjadi Kampung Islam Kepaon dikarenakan kondisi wilayah tersebut merupakan potret kampung kota. Berada di tengah dominasi Umat Hindu kampung islam kepaon mencoba untuk mengaktualisasikan keberadaan mereka ditengah arus modernisasi pusat kota Denpasar.

Pilar etimologi "kepaon" berasal dari kata paon yang berarti dapur. Pada jaman dahulu, saat upacara akan dimulai diperlukan berbagai macam makanan yang sudah siap saji. Proses makanan yang dimatangkan tersebut dilakukan oleh kelompok lain untuk membuat sebuah dapur suci yang khusus untuk keperluan upacara. Tempat memasak itu kemudian disebut Sunya Powaregan/ dapur suci. Paon yang mendapat kata depan "ke" memiliki arti pergi ke suatu tempat. Dapat ditarik benang merah bahwa kepaon memiliki arti datang ke 
Avaliable online at http://e-journal.unipma.ac.id/index.php/gulawentah

dapur untuk mencari perlengkapan upacara.

Pada Desa Adat Islam Kepaon atau disebut Kampung Islam Kepaon, seluruh masyarakat yang bertempat tinggal disana beragama islam. Rekam jejak umat islam yang berada di Bali diterima terbuka oleh masyarakat Bali yang mayoritas beragama Hindu. Banyak transmigran yang datang ke Bali untuk sebagai pemenuhan perekonomian melalui modal sosial yang dimiliki. Historical islam masuk ke bali bermula dari komunitas Muslim lama yang telah eksis sejak abad $15 \mathrm{M}$, di zaman kerajaan Gelgel era kepemimpinan Dalem Ketut Ngelesir. Tapak historis mereka juga dapat ditelusuri dari prasasti, bahkan mungkin juga bangunan-bangunan penting kerajaan di Puri, termasuk cap kerajaan Klungkung yang menggunakan huruf Arab karena pada zaman Raja Ida Bagus Jambe kerajaan ini telah menjalin hubungan diplomatik dengan sebuah kerajaan Islam di Jambi (Sumatera Selatan). Semua fakta historis tadi menjadi bukti bahwa Islam hakikatnya bukan fenomena baru di Bali, melainkan telah menjadi entitas dengan usiaratusan tahun, hampir sama tuanya dengan komunitas Muslim di daerah-daerah lain di Indonesia. Masyarakat Islam di Bali bersifat pluralistis karena berasal dari beberapa etnis, seperti Jawa, Madura Bugis, Keturunan Arab dan India. Ada beberapa kampung yang di tempati oleh masyarakat muslim di Bali, antara lain di daerah Negara yaitu Loloan Barat, Loloan Timur, Kampung Pangembangan, Banyubiru. Buleleng yaitu Kampung Bugis, Kampung Islam. Badung yaitu Kampung Islam
Kepaon.Menariknya, hanya kampung islam kepaon yang berada di tengah pusat kota Denpasar dan eksistensi kampung masih terjaga.

Berbicara tentang tradisi yang memiliki arti suatu tindakan yang dilakukan secara ajeg disuatu daerah dengan memasukkan unsur budaya yang diwariskan secara turun temurun pada masa lalu hingga saat ini, Bali salah satu provinsi dengan keberagaman tradisi yang kental dan kuat.Salah satu tradisi yang masih dijalankan sampai saat ini adalah Tradisi Megibung. Tradisi Megibung dimaknai dengan suatu proses kegiatan yang dilakukan oleh masyarakat atau sebagian orang utuk duduk bersama saling berbagi satu sama lain terutama dalam hal makanan. Megibung berasal dari kata gibung yang mendapat awalan Me-Gibung berarti kegiatan yang dilakukan oleh banyak orang dimana saling berbagi antara orang yang satu dengan orang yang lainnya, dan pada awalan me- berarti melakukan suatu kegiatan.Awal mula tradisi ini diprakarsai oleh masyarakat Karangasem yang daerahnya terletak di ujung timur Pulau Dewata.Keunikan dari tradisi ini menjadikan icon identitas Kabupaten Karangasem yang beribukota Amplapura.Eksistensi Megibung sudah ada sejak jaman dahulu kala hingga saat ini.

Potret pelaksanaan kegiatan megibung bisa dijumpai pada saat proses Upacara Adat dan Keagamaan di suatu tempat di Karangasem diantaranya seperti Upacara Dewa Yadnya contohnya seperti Odalan, Pitra Yadnya contohnya adalah Upacara Ngaben, Resi Yadnya, dan Manusia Yadnya seperti 


\section{gulawentah: Jurnal Studi Sosial}

Volume 2 Nomor 1 Juli 2017 hal 29-40

Avaliable online at http://e-journal.unipma.ac.id/index.php/gulawentah

Metatah (potong gigi) dan Pawiwahan. Proses kegiatan tersebut dilaksanakan secara individu (yang punya acara) atau masyarakat (seluruh masyarakat banjar). Pelaksana kegiatan tradisi megibung memberikan undangan kepada sanak saudara untuk menyaksikan prosesi kegiatan upacara keagamaan yang diadakan.Sehingga harapannya, proses upacara tersebut bisa berjalan dengan lancer sesuai dengan yang diharapkan.

Makna singkat dari megibung adalah makan bersama dengan tujuan kebersamaan sanak saudara.Peserta yang melaksanakan tradisi megibung ini terdiri dari 6-8 orang yang dibagi menjadi kelas gender laki-laki dan perempuan dengan duduk bersila. Makanan yang disajikan oleh pelaksana tradisi megibung diantaranya adalah Nasi yang ditaruh pada satu wadah besar , lauk sebagai pelengkap nasi (sate , lawar, pepesan ayam atau babi, lawar kowoh) yang ditempatkan pada satu wadah kecil. Adapun norma yang dijalankan pada tradisi megibung adalah pada saat makan tidak boleh ada yang terjatuh di dalam wadah nasi atau lauk serta jika terdapat salah satu peserta megibung sudah merasa kenyang,

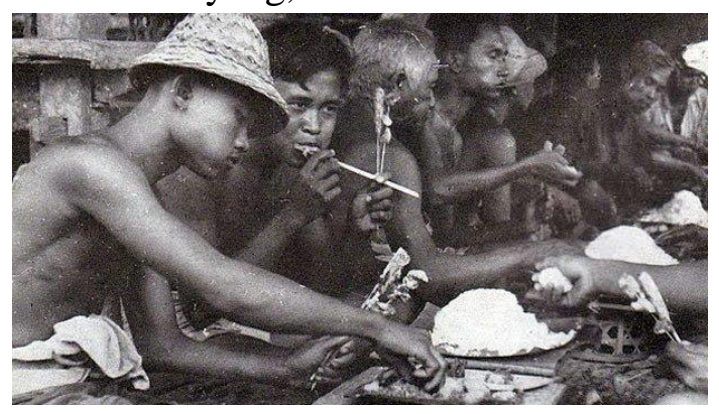

Gambar 2. Potret Megibung 1614 Caka peserta tersebut dilarang untuk meninggalkan tempat megibung dan wajib menunggu peserta lain selesai. Sebelum diadakan tradisi megibung, biasanya satu hari sebelum acara tersebut berlangsung para pelaksana kegiatan melakukan kegiatan mebat ,banten (sembahyang), kemudian baru melakukan megibung. Gambar dibawah ini adalah tradisi megibung 1614 CakaGambar 2. Potret Megibung 1614 Caka dan Gambar 3. Menu Megibung Umat Hindu. 
Avaliable online at http://e-journal.unipma.ac.id/index.php/gulawentah

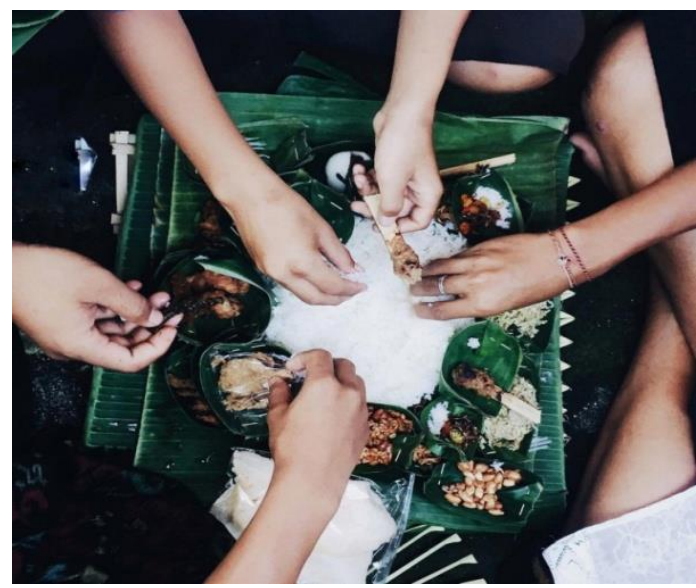

\section{Gambar 3. Menu Megibung Umat Hindu}

Megibung dilakukan di Banjar, Dadya atau Pura Dalem dan Pura Puseh. Di Banjar, tradisi megibung dilaksanakan oleh seluruh warga Banjar sedangkan di Dadya dilaksanakan oleh keluarga besar yang memiliki Pura/ Sanggah yang sama dalam satu ruang lingkup tempat tinggal. Ketentuan waktu pelaksanaan tradisi megibung dilakukan menurut perhitungan bulan (sasih) dan wuku (210 hari). Bagi Masyarakat Bali, Megibung mengandung makna yang sangat krusial terutama dalam hal kebersamaan saling berbagi satu sama lain tanpa melihat kasta dan materi yang dimiliki oleh seseorang. Sayangnya, seiring berjalannya waktu dan perkembangan dunia yang semakin pesat para kaum borjuis sudah mulai meninggalkan tradisi tersebut dan menggantikannya dengan memilih untuk memesan makanan melalui catering. Era modern sekarang ini, tradisi megibung untuk masyarakat Bali khususnya umat hindu sudah tidak menjadi keharusan untuk dilaksanakan mengingat masyarakat modern lebih mengingikan segala sesuatu yang bersifat praktis.Gambar Tradisi Megibung di Karangasem dapat dilihat pada gambar Gambar 4. Tradisi Megibung Umat Hindu.

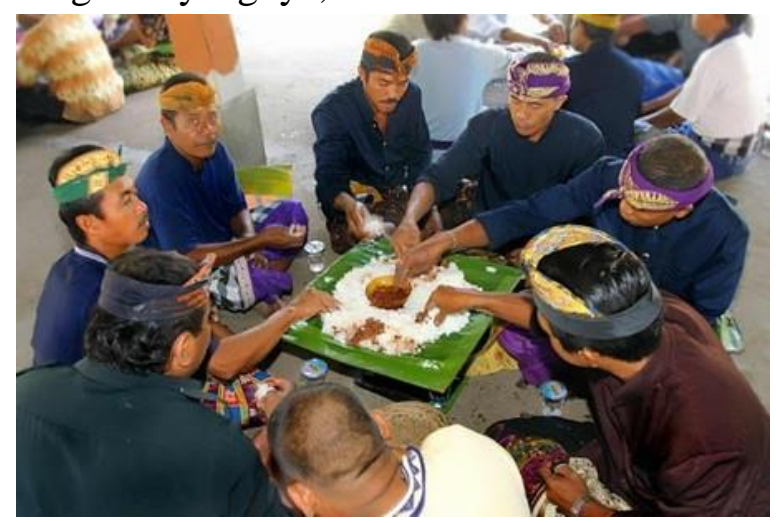

Gambar 4. Tradisi Megibung Umat Hindu

Terdapat penemuan yang menarik di salah satu Kampung Islam Denpasar yaitu Kampung Islam Kepaon.Salah satu tradisi Bali, yaitu Megibung masuk ke tradisi masyarakat Kampung Islam Kepaon.Tradisi masyarakat Bali tersebut 


\section{gulawentah: Jurnal Studi Sosial}

Volume 2 Nomor 1 Juli 2017 hal 29-40

Avaliable online at http://e-journal.unipma.ac.id/index.php/gulawentah

diterima baik oleh masyarakat Kampung Islam.Bahkan sebagai bentuk penanaman kearifan lokal Bali, mereka ikut melaksanakan tradisi Megibung. Mempunyai pemaknaan yang sama yakni makan bersama untuk menciptakan kebersamaan antar masyarakat yang ada di Kampung Islam Kepaon. Perbedaan tradisi megibung yang ada di Karangasem (dilakukan oleh umat hindu) dengan di Kepaon (dilakukan oleh Umat Islam) hanya makanan yang disajikan. Di Kampung Islam Kepaon, Megibung dilaksanakan tiga kali pada saat bulan Ramadhan yakni hari ke 10 , hari ke 20, dan hari ke 30 puasa Ramadhan. Proses memasak makanan tersebut dilakukan oleh ibu-ibu dari masing-masing RT di Kampung Kepaon dan dilaksanakan secara bergiliran. Makanan tersebut dijadikan pada satu tempat yang berisi Nasi, dan terdapat tempat lain dengan ukuran lebih kecil sebagai tempat sayur lauk pauk seperti masakan ayam-ayaman seperti ayam bumbu ganep, ayam panggang, olahan telur rebus atau telur goreng, dan sayur-sayuran seperti urap atau sayuran berkuah.Gambar 5. Suasana Buka Puasa Kampung Kepaon.

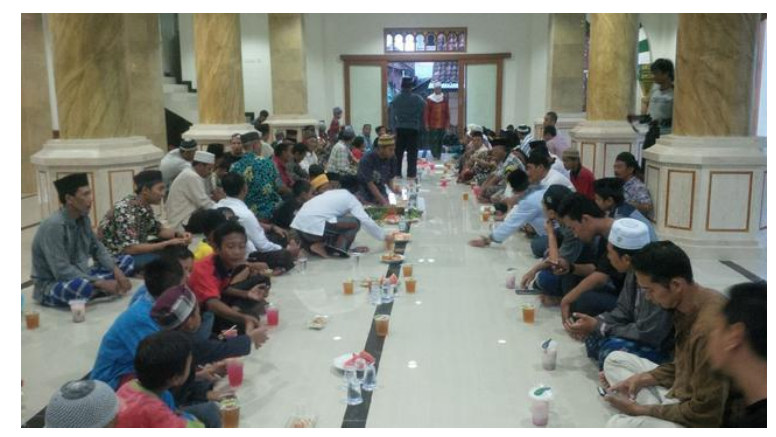

\section{Gambar 5. Suasana Buka Puasa Kampung Kepaon}

Proses pelaksanaan tradisi megibung di Kampung Islam Kepaon dilakukan di Masjid Al Muhajirin dengan dihadiri oleh jamaah masjid. Tradisi megibung dimulai dengan buka bersama makan-makanan ringan seperti Es Kolak, Jajan tradisional. Setelah buka puasa, mereka melaksanakan sholat maghrib berjamaah. Setelah sholat maghrib berjamaah, kelompok Jemaah masjid dibagi menjadi beberapa kelompok untuk mengelilingi tempat baki yang berisi nasi tumpeng beserta lauk pauknya. Salah satu tokoh agama islam yang ada di Kampung Kepaon membacakan doa sampai selesai. Setelah selesai membaca doa, tokoh agama akhirnya mempersilahkan para jamaah untuk melaksanakan tradisi megibung. Tradisi megibung dapat dilihat pada gambar Gambar 6. Potret Megibung Kampung Islam Kepaon 
Avaliable online at http://e-journal.unipma.ac.id/index.php/gulawentah

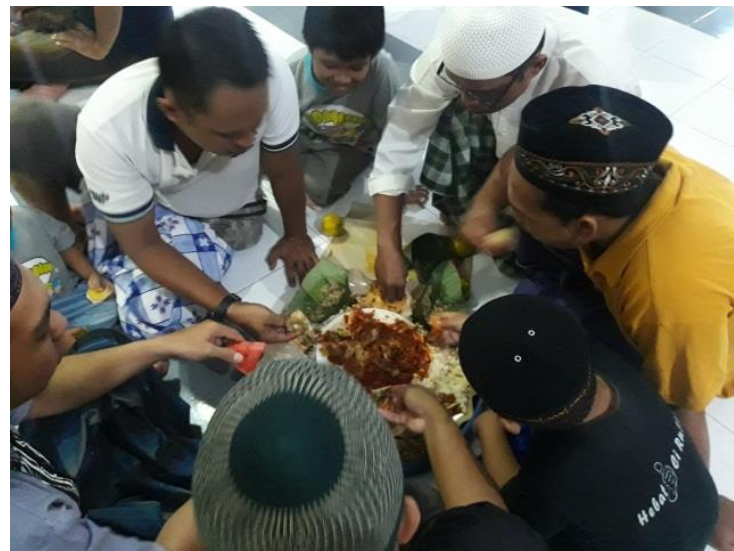

Gambar 6. Potret Megibung Kampung Islam Kepaon

Kebersamaan yang ada pada tradisi megibung merupakan keselarasan interpretasi dari Umat Hindu dan Umat Islam. Pencampuran tradisi ini berjalan tanpa ada perselisihan atas kepemilikan kebudayaan masing-masing. Berada dalam satu ruang lingkup ke-Bali-an, masyarakat kampung Islam Kepaon tidak meninggalkan adat budaya dan tradisi Bali sekalipun dalam identitas islam. Jejak rekam leluhur Putri Pemecutan Kaja yang bertransformasi agama dari Hindu ke Islam yaitu Raden Ayu Siti Khotijah (Gusti Ayu Made Rai) masih terasa hangat disana.Raden Ayu Siti Khotijah menikah dengan salah satu pangeran asal Madura Pangeran Cakraningrat IV yang beragama Islam.Padaa saat itu, Putri Pemecutan Kaja tersebut menjadi mualaf. Sejarah mengatakan bahwa Kampung Islam Kepaon adalah kampung yang memang dibentuk untuk umat islam oleh Raja Pemecutan Kaja. (Puger, 2014) Hingga saat ini, sinkritisme yang dibuktikan dengan eksistensi tradisi megibung di Kampung Islam Kepaon menjadi bukti bahwa Toleransi umat beragama masih terus mengakar hingga pada generasi penerus para leluhur di kampung tersebut.

\section{Kesimpulan}

Sinkretisasi hadir sebagai wujud penyeimbangan dua atau lebih dari suatuagama, tradisi atau budaya wilayah tertentu. Proses dimana elemen-elemen dari suatu agama terasimilasikan ke dalam agama lain sehingga menghasilkan perubahan mendasar dalam esensi maupu ajaran-ajaran agama tersebut. Tradisi Megibung merupakan modal budaya Kampung Islam Kepaon hasil dari adopsi tradisi megibung yang berasal dari Karangasem Bali.Prosesi pelaksanaan tradisi ini pada dasarnya memiliki kesamaan makna, perbedaannya hanya terletak pada menu makanan yang disajikan oleh pelaksana tradisi megibung. Pemaknaan tradisi ini menciptakan keselarasan toleransi dari agama yang berbeda di salah satu potret kampung berbasis agama di pusat kota yaitu Kampung Islam Kepaon Denpasar. Kampung Islam Kepaon menjalankan tradisi tersebut sebagai bentuk aktualisasi keberadaan masyarakat muslim di tengah dominasi masyarakat 
Avaliable online at http://e-journal.unipma.ac.id/index.php/gulawentah

umat hindu. Pembauran dua agama dalam satu tradisi ini menciptakan persatuan plurasime agama di Bali.

\section{Daftar Pustaka}

Basrowi dan Suwandi. (2008). Memahami Penelitian Kualitatif.Jakarta : Rineka Cipta.

Bungin, Burhan. (2011). Sosiologi Komunikasi : Teori, Paradigma, dan Diskursus Teknologi Komunikasi di Masyarakat. Jakarta: Kencana.

C.A. van Peursen. (1988). Strategi Kebudayaan.Jakarta: Kanisius

Koentjaraningrat.(1980). Pengantar Ilmu Antropologi. Jakarta: Aksara Baru.

Mulder, Niels. (1992). "Sinkretisme Agama atau Agama Asia Tenggara?'Basis, Agustus, p. 285

Puger, Jro Mangku I Made. (2014). Sejarah Keramat Agung Pemecutan Makam Raden Ayu Pemecutan Alias Raden Ayu Siti Khotijah.Denpasar

Simuh,.(1996). Sufisme Jawa Transformasi Tasawuf Islam Kemistik Jawa, Yogyakarta: Bentang Budaya

Siv Ellen Kra t,.(2002). "To mix or not to mix: Syncretism/ anti-syncretism in the history o theosophy," Numen: International Review for the History of Religions49, no. 2., 143-145

Yin, Robert K, (2014).Studi Kasus Desain \& Metode. Jakarta: PT. Raja Grafindo Persada

P.Ztompka.(2010).Sosiologi Perubahan Sosial. Jakarta : Prenada 